\title{
PENGEMBANGAN INSTRUMEN PENILAIAN KARAKTER UNTUK SISWA SEKOLAH DASAR (SD)
}

\author{
Khairun Nisa, Nurhasanah, Anindita SHM Kusuma*, Deni Sutisna, Mega Puspita Sari \\ Program Studi Pendidikan Guru Sekolah Dasar, FKIP Universitas Mataram, Indonesia \\ Corresponding author: Anindita_fkip@unram.ac.id
}

\section{Article History}

Received : April $21^{\text {th }}, 2021$

Revised : May $04^{\text {th }}, 2021$

Accepted : May $11^{\text {th }}, 2021$

Published : May $18^{\text {th }}, 2021$

\begin{abstract}
The issue of the character of the nation is still in the sharp spotlight by the community. The characters which at the same time include national culture cover various aspects of life. Even though it has long been echoed in every educational unit, character development seems to be the only writing that is always at the beginning of the lesson plan without any measurement tools. This research aims to explain the form of character assessment instruments developed for elementary school (SD) students. This type of research is development. The product produced from this development research is a character assessment instrument. The development design that will be used is the ADDIE instructional design. The results of internal validation of the instrument show that the questionnaire developed is very valid and can be used without improvement. External validation of the character assessment instrument for low classes, it is known that all statement items in the instrument are valid. The reliability of the low-class character assessment instrument was 0.986 in the first test and 0.984 in the second test. External validation of the character assessment instrument for high class, it is known that all statement items are valid. The reliability of the high-class character assessment instrument on the first test was 0.980 (very high) and on the second test was 0.979 (very high). Recommendations for development results are character assessment instruments that need to be tested in research on normal (offline) learning and still need to be evaluated (after being implemented) based on the input obtained from the response questionnaire or field notes on the observation sheet.
\end{abstract}

Keywords: Assesment, Character, Instrument

\section{PENDAHULUAN}

Permasalahan karakter bangsa masih menjadi sorotan tajam oleh masyarakat. Karakter yang sekaligus mencakup budaya bangsa meliputi berbagai aspek dalam kehidupan. Persoalan yang dimaksud sudah banyak tertuang di berbagai tulisan media cetak maupun elektronik. Selain ulasan-ulasan di media cetak dan elektronik, para ahli dan pengamat bahkan pemuka agama dan sosial juga berbicara tentang persoalan karakter dan budaya bangsa dalam berbagai forum diskusi.

Persoalan yang sedang marak terjadi seperti tawuran remaja, perusakan, perkelaian antar siswa, pemukulan guru oleh siswa, pemukulan siswa oleh guru, pelecehan seksual, narkoba dan miras yang melibatkan siswa sekolah dan lain sebagainya selalu menjadi headline dan topik perbincangan hangat di kalangan masyarakat. Berbagai upaya dan alternatif penyelesaian masalah diajukan seperti regulasi peraturan, undang-undang, peningkatan upaya pelaksanaan dan penerapan hukum yang lebih kuat.

Alternatif lain juga diajukan oleh para pakar untuk mengatasi persoalan karakter tersebut, paling tidak dapat mengurangi atau meminimalisir persoalan karakter yakni melalui pendidikan. Pendidikan dianggap sebagai alternatif yang bersifat preventif (pencegahan) karena pendidikan membangun generasi baru bangsa yang lebih baik. Pendidikan diharapkan dapat mengembangkan kualitas generasi bangsa dalam berbagai aspek yang dapat meminimalisir dan mengurangi penyebab berbagai masalah karakter. Jenjang pendidikan mulai dari TKSMA menjadi fokus untuk menanamkan pendidikan karakter yang baik meskipun tidak terlihat dampaknya dalam waktu yang cepat.

Selain masyarakat yang sangat peduli mengenai pendidikan budaya dan karakter bangsa, pemerintah juga memiliki kepedulian yang sama. Melalui Kementerian Pendidikan 
Nasional pada awal tahun 2010, pemerintah menggambarkan adanya kebutuhan masyarakat yang kuat akan pendidikan budaya dan karakter bangsa. Keinginan masyarakat dan kepedulian pemerintah mengenai pendidikan budaya dan karakter bangsa, akhirnya berbuah pada kebijakan pemerintah mengenai pendidikan budaya dan karakter bangsa dan menjadi salah satu program unggulan pemerintah, paling tidak untuk masa 5 tahun mendatang.

Meskipun sudah lama digaungkan di tiap satuan pendidikan, pengembangan karakter sepertinya hanya tulisan yang selalu ada di bagian awal rencana pelaksanaan pembelajaran tanpa ada alat ukurnya. Jika ada pun, instrumen karakter yang digunakan adalah instrumen afektif maupun psikomotor yang pada akhirnya tumpang tindih, diakhir penilaian tidak bisa dibedakan antara mana afektif, psikomotor dan mana karakter.

Latifah (2017) melalui penelitiannya yang berjudul "Implementasi Pendidikan Karakter di Sekolah Dasar Nahdatul Ulama Sleman", menilai karakter baru menggunakan lembar observasi dan wawancara dengan guru. Lembar observasi yang digunakan yang lebih mengarah kepada observasi aktifitas siswa di dalam kelas bukan menilai karakter. Wawancara terhadap guru juga terbatas pada bagaimana cara pengimplementasian karakter dalam pembelajaran, bukan bagaimana cara menilai karakter siswa.

Sejalan dengan hal tersebut, Rusmana (2019) menjelaskan bahwa beberapa penguatan karakter di Sekolah Dasar seperti religius yang dilakukan dalam kegiatan di sekolah seperti berdoa sebelum dan sesudah belajar, sholat berjamaah, dan sebagainya. Nilai karakter peduli lingkungan diterapkan melalui kegiatan bersihbersih bersama, mengumpulkan botol bekas, membuang sampah pada tempatnya, dan melaksanakan piket harian. Nilai karakter tanggung jawab diterapkan agar kesalahan yang mereka lakukan dan berani untuk bertanggung jawab serta meminta maaf atas kesalahan yang mereka lakukan. Nilai karakter kejujuran diterapkan dalam kegiatan harus jujur dalam mengerjakan ujian dan tidak boleh menyontek. Nilai karakter disiplin diterapkan dalam hal datang tepat waktu, mematuhi segala aturan yang ada dan sebagainya. Beberapa penguatan karakter tersebut hanya dinilai berdasarkan observasi dari sudut pandang peneliti.

Darmayanti dan Wibowo (2014) mengemukakan bahwa dalam menilai karakter sebaiknya sekolah perlu membuat perencanaan yang jelas mengenai pencapaian indkator nilai karakter.

Berdasarkan hal-hal tersebut, maka dalam penelitian ini akan mengembangkan instrumen penilaian karakter yang difokuskan pada siswa di Sekolah Dasar (SD). Pengembangan instrumen penilaian karakter berdasarkan indikator yang telah ditetapkan oleh Kemendiknas (2010). Indikator yang akan dikembangkan menjadi instrumen penialain karakter adalah jujur, disiplin, toleransi, kreatif, cinta damai, gemar membaca, rasa ingin tahu, semangat kebangsaan, cinta tanah air, mandiri, bersahabat/komunikatif, peduli lingkungan.

\section{METODE}

Penelitian merupakan penelitian pengembangan. Produk yang dihasilkan dari penelitian pengembangan ini berupa instrumen penilaian karakter. Desain instruksional pengembangan yang akan digunakan dalam penelitian ini adalah ADDIE (Branch, 2009). Tahapan dalam desain instrusional ADDIE meliputi tahap Analysis (Analisis), Design (Perancangan), Develop (Pengembangan), Implement (Implementasi) dan Evaluate (Evaluasi). Tahap pengembangan merupakan tahap realisasi produk. Pada tahap ini pengembangan instrumen angket karakter dilakukan sesuai dengan rancangan. Setelah itu, angket tersebut akan divalidasi oleh ahli (validasi internal). Setelah validasi ahli (validasi internal), maka dilanjutkan dengan validasi eksternal. Validasi eksternal melibatkan siswa-siswa SD di kota mataram sebagai sampel uji coba instrument karakter. Validasi eksternal dilakukan untuk mengetahui validitas dan reliabilitas item instrument karakter.

\section{HASIL DAN PEMBAHASAN}

Pengujian validitas internal oleh ahli dilakukan sebanyak dua kali. Pada validasi yang pertama terhadap instrument penilaian karakter untuk siswa kelas rendah diperoleh nilai validasi dari ahli I sebesar 60\%. Dengan kesimpulan bahwa instrument yang dikembangkan kurang valid dan perlu banyak perbaikan. Pada validasi yang pertama terhadap instrument penilaian karakter untuk siswa kelas tinggi diperoleh nilai validasi dari ahli II sebesar $63 \%$.

Berdasarkan hasil tersebut maka dilakukan perbaikan sesuai kekurangan dan saran dari validator. Setelah selesai dilakukan perbaikan 
maka, dilakukan validasi internal yang kedua. Pada validasi internal yang kedua diperoleh nilai diketahui bahwa nilai validitas yang diperoleh dari validator I adalah 93,33\% dengan kesimpulan bahwa angket yang dikembangkan sangat valid dan dapat digunakan tanpa perbaikan. Nilai validitas yang diperoleh dari validator II adalah sebesar 95\% dengan kesimpulan bahwa angket yang dikembangkan sangat valid dan dapat digunakan tanpa perbaikan.

Berdasarkan uji coba dan hasil analisis validitas terhadap instrument penilaian karakter untuk kelas rendah yang pertama diketahui bahwa keseluruhan item pernyataan dalam instrument yang valid. Reliabilitas instrument penilaian karakter sebesar 0,986 sehingga dapat disimpulkan bahwa instrument penilaian karakter memiliki reliabilitas sangat tinggi. Uji coba kedua dilakukan untuk melihat konsistensi nilai reliabilitas instrument. Azwar (2013) menjelaskan bahwa reliabilitas menjelaskan sejauh mana hasil suatu pegukuran dapat dipercaya. Reliabilitas memiliki berbagai nama seperti kepercayaan, keterandalan, keajegan, kestabilan, konsistensi dan sebagainya. Dalam bidang psikologi dan pendidikan, reliabilitas (keandalan) instrument diartikan sebagai konsistensi hasil dari instrument tersebut. Artinya, suatu instrument dikatakan memiliki keterandalan sempurna, ketika hasil pengukuran berkali-kali terhadap objek pengukuran yang sama selalu menunjukkan hasil atau skor yang sama. Pada pengujian kedua diperoleh nilai reliabilitas sebesar 0,984 (sangat tinggi). Pada pengujian kedua, hasil analisis validitas menunjukkan bahwa semua item pernyataan dalam instrument adalah valid.

Analisis validitas dan reliabilitas juga dilakukan terhadap instrument penilaian karakter untuk siswa SD kelas tinggi. Berdasarkan uji coba dan hasil analisis validitas terhadap instrument penilaian karakter untuk kelas tinggi yang pertama diketahui bahwa keseluruhan item pernyataan dalam instrument yang valid. Reliabilitas instrument penilaian karakter adalah sebesar 0,980 sehingga dapat disimpulkan bahwa instrument penilaian karakter memiliki reliabilitas sangat tinggi. Pada pengujian kedua diperoleh nilai reliabilitas sebesar 0,979 (sangat tinggi).

\section{Pembahasan}

Instrument yang telah dikembangkan berupa instrument penilaian karakter yang mengacu pada Pengembangan Pendidikan Budaya dan Karakter Bangsa: Pedoman Sekolah. Kementerian Pendidikan Nasional, Badan Penelitian dan Pengembangan Pusat Kurikulum, Kementerian Pendidikan dan Kebudayaan Nasional RI (Kemendiknas, 2010). Instrumen penilaian karakter yang telah dikembangkan diperuntukan bagi siswa SD kelas rendah (kelas 1-3) dan siswa SD kelas tinggi (4-6). Beberapa karakter yang menjadi acuan pengembangan instrument adalah karakter jujur, toleransi, disiplin, kerja keras, mandiri,

Masing-masing indikator tersebut kemudian dirumuskan menjadi item-item pernyataan yang representatif dan menggambarkan indikator karakter. Azwar (2013) mengemukakan bahwa sebagai sebuah konsep yang bersifat teoritik, atribut psikologi (termasuk karakter), menurut Azwar tidak mungkin diukur secara langsung karena konsep ini merupakan sebuag abstraksi dari ide atau gagasan mengenai sesuatu. Pengukuran terhadap atribut psikologi dalam hal ini adalah karakter hanya dapat dilakukan secara tidak langsung melalui indikator keperilakuan (behavioral indicators). Indikator keperilakuan ini menjadi dasar dalam pembuatan pernyataan sebagai point of stimulus dalam skala yang dikenal dengan item.

Item-item pernyataan dalam instrument penilaian karakter yang rumusannya operasional dan berada dalam tingkat kejelasan yang dapat diukur (measureable) dan dapat $\mathrm{di}$ kuantifikasikan. Item pernyataan masing-masing indikator dirumuskan menjadi pernyataan positif dan negative yang masing-masing memiliki skala dan memiliki skor. Misalnya, item 1 pernyataan positif jika siswa menjawab sangat setuju (SS) maka untuk pernyataan itu skor yang diperoleh 4 , jika menjawab setuju (S) maka skor yang diperoleh 4, jika menjawab tidak setuju (TS) maka skor yang diperoleh 2 dan jika menjawab sangat tidak setuju (STS) skor yang diperoleh 1. Berkebalikan dengan skor item pernyataan positif, pada item pernyataan negatif, jika siswa menjawab sangat setuju (SS) maka skor yang diperoleh 1, jika menjawab setuju (S) maka skor yang diperoleh 2 , jika menjawab tidak setuju (TS) maka skor yang diperoleh 3 dan jika menjawab sangat tidak setuju (STS) maka skor yang diperoleh 4.

Tahapan yang dilakukan setelah instrument selesai dikembangkan adalah menguji 
validitasnya (secara internal maupun eksternal). Richey (2007) mengemukakan bahwa terdapat lima pendekatan dalam pengujian produk hasil pengembangan, tiga macam untuk pengujian validitas internal (expert review, use ability documentation dan component investigation) dan ada dua macam dalam pengujian eksternal (field evaluation dan control testing).

Pengujian validitas internal oleh ahli (expert review). Setelah uji validitas internal selesai dilakukan maka dilakukan uji validitas eksternal secara terbatas. Untuk instrument kelas rendah menggunakan sampel 21 siswa dan untuk kelas tinggi menggunakan sampel sebanyak 25 siswa secara offline dengan bantuan guru kelas. Uji validitas eksternal dimaksudkan untuk memperoleh data validitas dan reliabilitas instrument. Instrumen penilaian karakter yang telah dikembangkan kemudian diuji validitasnya. Azwar (2013) menjelaskan bahwa kualitas instrumen yang akan digunakan dalam penelitian adalah sangat penting, sebagai penyelesaian dari suatu pengambaran yang didasarkan dari informasi yang diperoleh menggunakan instrumen tersebut. Beberapa kriteria yang harus dipenuhi oleh suatu instrumen penelitian supaya dapat dinyatakan memiliki kualitas yang baik yaitu instrument yang memiliki validitas dan reliabilitas. Suatu instrumen dinyatakan telah memiliki validitas (kesahihan) yang baik jika instrumen tersebut benar-benar mengukur apa yang seharusnya hendak diukur. Reliabilitas menjelaskan sejauh mana hasil suatu pengukuran dapat dipercaya. Reliabilitas memiliki berbagai nama seperti kepercayaan, keterandalan, keajegan, kestabilan, konsistensi dan sebagainya. Suatu instrumen dikatakan memiliki keterandalan sempurna, ketika hasil pengukuran berkali-kali terhadap subjek yang sama selalu menunjukkan hasil atau skor yang sama. Pengujian validitas dan reliabilitas eksternal dilakukan sebanyak dua kali.

Azwar (2013) juga menjelaskan bahwa reliabilitas dapat terkait dengan beberapa aspek validitas, seperti validitas deskriptif yaitu apabila pengamatan atau metode yang berbeda terhadap peristiwa atau situasi yang sama menghasilkan data atau laporan yang berbeda secara deskriptif. Namun demikian, konsep reliabilitas tidak sama dengan validitas. Suatu tes yang mengukur apa yang seharusnya diukur biasanya akan memberikan hasil pengukuran yang konsisten dari waktu ke waktu (tes yang valid biasanya reliabel). Akan tetapi suatu tes yang memberikan suatu hasil yang konsisten mungkin dapat mengukur hal yang sama sekali salah (tes yang reliabel belum tentu valid).

Reliabilitas instrument penilaian karakter yang telah dikembangkan adalah sebesar 0,980 sehingga dapat disimpulkan bahwa instrument penilaian karakter memiliki reliabilitas sangat tinggi. Pada pengujian kedua diperoleh nilai reliabilitas sebesar 0,979 (sangat tinggi). Berkaitan dengan nilai reliabilitas yang tidak sempurna (reliabilitas sempurna yakni bernilai 1) meskipun semua item valid, Azwar (2013) menjelaskan bahwa dalam praktiknya, kita hampir tidak pernah mendapatkan instrument yang memiliki reliabilitas sempurna. Skor atau data yang kita peroleh dari pengukuran terhadap seorang subjek secara berulang-ulang dengan alat yang sama, pada umumnya berbeda besarnya. Artinya dalam hasil pengukuran itu terdapat kesalahan (error).

Pada pengujian kedua, hasil analisis validitas menunjukkan bahwa semua item pernyataan dalam instrument adalah valid. Menilik dari nilai reliabilitas pada pengujian pertama dan kedua baik intrumen penilaian karakter untuk kelas rendah maupun kelas tinggi maka dapat disimpulkan bahwa instrument penilaian karakter yang telah dikembangkan reliabel dan dapat digunakan untuk penelitian lebih lanjut. Tahap penelitian lebih lanjut yang dimaksudkan disini adalah menguji coba efektifitas instrument yang telah dikembangkan ke dalam situasi pembelajaran normal. Setelah implementasi maka yang seharusnya dilakukan adalah melakukan evaluasi. Evaluasi merupakan revisi terakhir terhadap instrumen penilaian karakter yang dikembangkan berdasarkan masukan yang didapat dari angket respon atau catatan lapangan pada lembar observasi. Hal ini bertujuan agar instrumen karakter yang dikembangkan benar-benar sesuai dan dapat digunakan oleh sekolah dalam cakupan yang lebih luas lagi. Akan tetapi karena kondisi saat ini sedang pandemik COVID-19 maka penelitian dapat dilakukan setelah pandemik berakhir dan pembelajaran di sekolah sudah kembali normal.

\section{KESIMPULAN}

Kesimpulan dalam penelitian pengembangan ini yakni sebagai berikut, 1) Instrumen yang telah dikembangkan berupa instrument penilaian karakter yang mengacu pada Pengembangan Pendidikan Budaya dan Karakter Bangsa: Pedoman Sekolah. Kementerian Pendidikan Nasional, Badan 
Penelitian dan Pengembangan Pusat Kurikulum, Kementerian Pendidikan dan Kebudayaan Nasional RI. Instrumen penilaian karakter yang telah dikembangkan diperuntukan bagi siswa SD kelas rendah (kelas 1-3) dan siswa SD kelas tinggi (4-6). Item-item pernyataan dalam instrument penilaian karakter yang rumusannya operasional (dirumuskan menjadi pernyataan positif dan pernyataan negative) dan berada dalam tingkat kejelasan yang dapat diukur (measureable) dengan skor masing masing pernyataan adalah 1-4, 2) Validasi internal terhadap instrument dilakukan sebanyak dua kali dan diketahui bahwa nilai validitas akhir yang diperoleh dari validator I adalah 93,33\% dan validator II adalah sebesar 95\% dengan kesimpulan bahwa angket yang dikembangkan sangat valid dan dapat digunakan tanpa perbaikan, 3) Validasi eksternal terhadap instrument penilaian karakter untuk kelas rendah dilakukan sebanyak dua kali. Pada pengujian pertama dan kedua diketahui bahwa semua item pernyataan dalam instrument penilaian karakter adalah valid. Reliabilitas instrument penilaian karakter adalah sebesar 0,986 pada pengujian pertama dan sebesar 0,984 pada penguijian kedua, 4) Validasi eksternal terhadap instrument penilaian karakter untuk kelas tinggi juga dilakukan sebanyak dua kali. Pada pengujian pertama dan kedua diketahui bahwa semua item pernyataan dalam instrument penilaian karakter adalah valid. Reliabilitas instrument penilaian karakter adalah sebesar 0,980 sehingga dapat disimpulkan bahwa instrument penilaian karakter memiliki reliabilitas sangat tinggi. Pada pengujian kedua diperoleh nilai reliabilitas sebesar 0,979 (sangat tinggi).

\section{UCAPAN TERIMA KASIH}

Kami segenap tim penelitian mengucapkan terima kasih kepada Dekan FKIP yang telah memberikan kesempatan kepada kami untuk melaksanakan penelitian ini. Terimakasih juga kami sampaikan kepada Universitas Mataram melalui Lembaga Penelitian dan Pengabdian kepada Masyarakat yang telah membiayai kegiatan penelitian serta kepada semua pihak yang tidak bisa disebutkan satu persatu yang telah membantu selama penelitian hingga artikel ini selesai.

\section{REFERENSI}

Akbar, S. (2017). Instrumen Perangkat Pembelajaran. Bandung: Remaja Rosdakarya.

Arikunto, S. (2001). Dasar-dasar Evaluasi Pendidikan. Edisi Revisi. Jakarta: Bumi Aksara.

Arikunto, S. (2006). Prosedur Penelitian: Suatu Pendekatan Praktik. Jakarta: Rineka Cipta.

Azwar, S. (2013). Penyusunan Skala Psikologi. Yogyakarta: Pustaka Belajar.

Azwar, S. (2013). Validitas dan Reliabilitas. Yogyakarta: Pustaka Belajar.

Borba, M. (2008). Membangun Kecerdasan Moral: Tujuh Kebajikan Utama Agar Anak Bermoral Tinggi. Terj. oleh Lina Jusuf. Jakarta: PT. Gramedia Pustaka Utama.

Branch, R. M. (2009). Instructional Design: The ADDIE Approach. New York: Springer Media \& Business, LLC.

Darmayanti, S.E \& Wibowo, U. B. (2014). Evaluasi Program Pendidikan Karakter di Sekolah Dasar Kabupaten Kulon Progo. Jurnal Prima Edukasia Volume 2 Nomor 2 Tahun 2014.

Kemendiknas (2010). Pengembangan Pendidikan Budaya dan Karakter Bangsa: Pedoman Sekolah. Kementerian Pendidikan Nasional: Badan Penelitian dan Pengembangan Pusat Kurikulum.

Latifah, F. (2017). Implementasi Pendidikan Karakter di Sekolah Dasar Nahdlatul Ulama Sleman. Skripsi tidak diterbitkan. Yogyakarta: Universitas Negeri Yogyakarta.

Lickona, T. (1991). Educating for Character: How Our School Can Teach Respect and Responsibility. New York, Toronto, London, Sydney, Auckland: Bantam books. 
Khairun Nisa et al. (2021). Jurnal Ilmiah Profesi Pendidikan, 6 (1): 102 - 107 DOI: https://doi.org/10.29303/jipp.v6i1.158

Rusmana, A. O. (2019). Penerapan Pendidikan Karakter di SD. Jurnal Eduscience Volumen 4 Nomor 2 Februari 2019.
Sugiyono. (2019). Metode Penelitian dan Pengembangan. (Research and Development). Yogyakarta: Alfabeta. 